\title{
זвхнологичиекив:TC 4/2018
}

Manko T. A. ${ }^{1}$, Gysarova I. A. ${ }^{2}$, Romenskaya O. P. ${ }^{2}$, Samusenko A. A. ${ }^{2}$, Derevianko I. I. ${ }^{2}$

1 Oles Honchar Dnipro National University. Ukraine, Dnipro

${ }^{2}$ Yuzhnoye, State-owned Design Office named after M. K. Yangel. Ukraine, Dnipro

\section{EVALUATION OF CARBON-PLASTIC TUBE STRUCTURES STRENGTH PROPERTIES UNDER THE INFLUENCE OF INTERNAL UNIAXIAL PRESSURE}

Carbon-plastics are widely applied in integrated launch vehicle (ILV) structures. They are rocket motor cases, nozzle cluster elements, forebodies etc. Characteristics of applied materials are defined at plate samples and models, simulating technology of structures manufacturing.

The paper considers carbon-plastics as a part of tube structures, manufactured from traditional fillers as well as modified under plasma treatment ones. It is performed the comparative analysis of carbon-plastic characteristics, obtained during mechanical tests of plate samples and internal pressure tests of models. [dx.doi.org/10.29010/085.9]

Keywords: carbonplastic; plasma; tube structure; tests.

\section{Introduction}

Development of new materials plays a key role in the aviation, space and prospective rocket systems for improving of the mass structures finishing. Emerging of materials in particular carbon fiber reinforced plastic (CFRP), fiberglass and organoplastic significantly expanded the scope of the composites application in aircrafts.

The most promising materials for aerospace and aviation technology are carbon plastics - polymer composite materials based on carbon fibers. The properties of CFRP are determined by the composition, type of polymer matrix, type and texture of the filler, their interaction at the phases of semi-finished products obtaining, material formation and products manufacturing from it, the level and ratio of elastic, strength and deformation characteristics of the components included into material composition. Existing technologies allow obtaining structures of various shapes, including those made by winding or laying-out.

Currently, considerable attention is paid to the issues of adhesive strength at the interface of the fillerresin compound.

\section{Research Objective}

At Yuzhnoye State Design Office named afrter M.K. Yangel it has been developed a method for increasing the adhesion strength of CFRP obtained by winding method at the filler-resin interface by modifying the filler (carbon fibers) by atmospheric plasma treatment in two different media, acrylic acid and allylamine. The application of treated carbon fiber made it possible to increase the physicomechanical characteristics of carbon fiber up to 25\% [1].
The purpose of this paperwork is to study the physicomechanical characteristics of carbon-plastic tube structures that modeling the technology of winding of rocket-space technology structures (solid rocket motors cases and liquid-propellant tanks), which use a filler modified by atmospheric plasma.

\section{Study Object}

The object of the research was thin-walled carbonplastic shells of tube shape with a height of $390 \mathrm{~mm}$, an inner diameter of $146 \mathrm{~mm}$, a wall thickness of $\sim 2 \mathrm{~mm}$ made by prepreg winding at an angle of $\pm 57^{\circ}$ to obtain an equally strong structure.

Carbon fibers of the following types were used as filler: T300 (УКН/5000 fiber) and T800 (IMS 65 24K fiber), both in the initial state and modified by atmospheric plasma treatment in acrylic acid and allylamine medium.

The thin-walled carbon plastic shell of a tube shape is shown in Figure 1.

\section{Research Methodology}

Destruction type of the winding composite shells of tube shape differs from plate analog samples by the absence of the "effect of the cut threads" and because of the weaving of binders during winding. Therefore, they are not chipped along the fibers, but the structure distortion of the filler.

Tube shells in comparison with plate-shaped samples, make possible to estimate the characteristics of CFRP with a greater degree of approximation [2].

The study of the physicomechanical properties of carbon-fiber wound structures was implemented on 


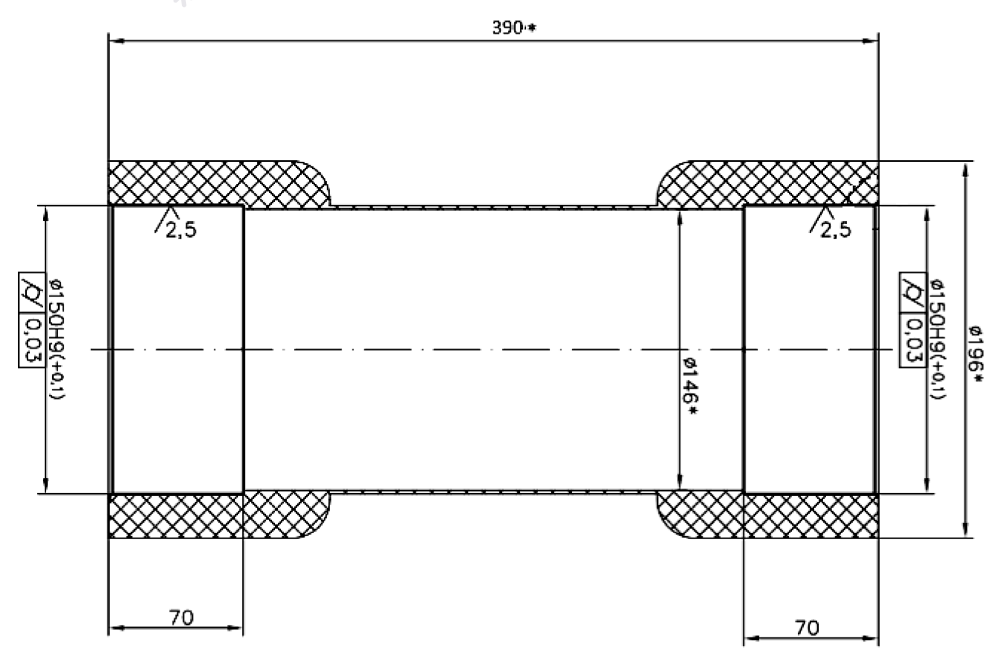

Fig. 1. Thin-walled carbon-plastic shell of a tube shape

tube samples under loading with internal pressure (the maximum pressure during fracture was $11.18 \mathrm{MPa}$ ). The ultimate strength, the relative deformation and the modulus of elasticity $\mathrm{E}$ of the material, as well as the nature of changes in these characteristics during loading at the installation sites of strain gauges were determined.

The essence of the method consists in measuring of the internal pressure and deformations in the circular $(\varepsilon 2)$ and axial ( $\varepsilon 1)$ directions. According to values obtained, it is possible to determine the above listed elastic characteristics.

Processing of test results was performed in the following order:

- determination of tensile strength $\sigma$

$$
\sigma=\frac{\frac{r_{1}^{2}}{r_{2}^{2}} \cdot L \cdot p}{2 \cdot N \cdot \sin \varphi}
$$

where $q_{\text {разр }}$ - internal pressure during sample destruction;

$r_{2}$ - internal radius of sample;

$r_{1}$ - external radius of sample $\left(r_{1}=r_{2}+\delta\right.$, where $\delta$ thickness of sample wall);

$L=15$ - filler laying-out step, $\mathrm{cm}$;

$p$ - internal breaking pressure, $\mathrm{MPa}$;

$N=14$ - number of filler layers;

$\varphi= \pm 57$ - angle of filler laying-out.

- determination of relative deformation $\varepsilon$

$$
\varepsilon=k \cdot A
$$

where $k=\frac{\Delta R \cdot 100}{R \cdot S \cdot n}-$ scale division of registering

device, $\% / \mathrm{mm}$ (herein $\Delta R$ - incrementation of bridge active shoulder resistance;

$R$ - strain gauge resistance;
$S=2$ - strain gage strain-sensitiveness;

$n$ - readings of the registering device at 1 unbalance);

$A$ - current value of reading.

- elastic modulus determination $E$

$$
E=\frac{\sigma}{\varepsilon}
$$

\section{Research Results}

The paper describes the testing results performed according to this method. Hydraulic tests were carried out with an internal pressure of six thin-walled carbonfiber shells of tube shape (from traditional (in the initial state) and carbon fibers treated with atmospheric plasma) to failure and the values of material deformation in the structure were determined.

Table 1 describes the results of calculations of the characteristics of the material of carbon-plastic tube structures based on traditional УКН/5000 and IMS65 carbon fibers, treated with atmospheric plasma in the acrylic acid and allylamine medium.

The presented results made it possible to conclude that the material characteristics, obtained on the wound tube models differ from those obtained on the plate samples (Table 2).

For instance, ultimate tensile strength of plate sample made of carbon plastic from traditional УКН/5000 carbon fiber is $666 \mathrm{MPa}$, for carbon plastic from tube structure this measures is up to $25 \%$ higher and presents $891 \mathrm{MPa}$

This indicates that in order to perform a specified calculation of the strength of the material of the structure, it is necessary to take into account the characteristics presented in Table 1. Moreover, the additional calculation of tube structures made by the winding method with a reinforcement angle of $\pm 57^{\circ}$ will make it possible to determine the minimum safety factor more accurately.

Also, to obtain more complete information about the interlayer strength of materials, microstructural 
The results of calculations of the carbon plastic strength characteristics, obtained by tube structures testing

\begin{tabular}{|c|c|c|c|c|c|c|c|}
\hline \multirow{2}{*}{$\begin{array}{c}\text { Material } \\
\text { of tube structure } \\
\text { (carbon-plastic) }\end{array}$} & \multirow{2}{*}{$\begin{array}{c}\text { Internal } \\
\text { pressure } \\
\text { during } \\
\text { ultimate } \\
\text { breaking } \\
\text { stress, MPa }\end{array}$} & \multicolumn{2}{|c|}{$\begin{array}{c}\text { Strength at } \\
\text { stretching } \sigma, \mathrm{MPa}\end{array}$} & \multicolumn{2}{|c|}{$\begin{array}{l}\text { The modulus of } \\
\text { elasticity } E \text {, GPA }\end{array}$} & \multicolumn{2}{|c|}{$\begin{array}{c}\text { Relative } \\
\text { deformation } \varepsilon, \%\end{array}$} \\
\hline & & $\begin{array}{l}\text { in axial } \\
\text { direction }\end{array}$ & $\begin{array}{c}\text { in the } \\
\text { circular } \\
\text { direction }\end{array}$ & $\begin{array}{c}\text { in axial } \\
\text { direction }\end{array}$ & $\begin{array}{l}\text { in the } \\
\text { circular } \\
\text { direction }\end{array}$ & $\begin{array}{c}\text { in axial } \\
\text { direction }\end{array}$ & $\begin{array}{l}\text { in the } \\
\text { circular } \\
\text { direction }\end{array}$ \\
\hline УКН/5000 (traditional) & 8,83 & 891 & 873 & 29 & 29 & 0,3062 & 0,3062 \\
\hline $\begin{array}{l}\text { УКН/5000, modified by plasma } \\
\text { in the acrylic acid medium }\end{array}$ & - & 1020 & 999 & 32 & 31 & 0,3225 & 0,3225 \\
\hline $\begin{array}{l}\text { УКН/5000, modified by plasma } \\
\text { in the allylamine medium }\end{array}$ & 9,61 & 970 & 951 & 31 & 31 & 0,3099 & 0,3099 \\
\hline IMS65 (traditional) & 11,18 & 1129 & 1106 & 33 & 32 & 0,3468 & 0,3468 \\
\hline $\begin{array}{l}\text { IMS65, modified by plasma in } \\
\text { the acrylic acid medium }\end{array}$ & 10,00 & 1000 & 980 & 34 & 34 & 0,2923 & 0,2923 \\
\hline $\begin{array}{l}\text { IMS65, modified by plasma in } \\
\text { the allylamine medium }\end{array}$ & 8,53 & 861 & 844 & 34 & 33 & 0,2543 & 0,2543 \\
\hline
\end{tabular}

Table 2

\section{Comparison of CFRP characteristics obtained on tube structures and plate samples with a reinforcement scheme of $\pm 57^{\circ}$}

\begin{tabular}{|c|c|c|c|c|}
\hline \multirow{3}{*}{ Углепластик } & \multicolumn{4}{|c|}{ Breaking stress, MPa } \\
\hline & \multicolumn{2}{|c|}{ on tube structure } & \multicolumn{2}{|c|}{ on plate samples } \\
\hline & $\begin{array}{l}\text { in axial } \\
\text { direction }\end{array}$ & $\begin{array}{l}\text { in the circular } \\
\text { direction }\end{array}$ & $\begin{array}{c}\text { across } \\
\text { reinforcement }\end{array}$ & $\begin{array}{c}\text { along the reinforcement } \\
\text { direction }\end{array}$ \\
\hline УКН/5000 (traditional) & 891 & 873 & 666 & 124 \\
\hline $\begin{array}{l}\text { УКН/5000, modified by plasma } \\
\text { in the acrylic acid medium }\end{array}$ & 1020 & 999 & 687 & 130 \\
\hline $\begin{array}{l}\text { УКН/5000, modified by plasma } \\
\text { in the allylamine medium }\end{array}$ & 970 & 951 & 676 & 119 \\
\hline IMS65 (traditional) & 1129 & 1106 & 961 & 148 \\
\hline $\begin{array}{l}\text { IMS65, modified by plasma } \\
\text { in the acrylic acid medium }\end{array}$ & 1000 & 980 & 982 & 170 \\
\hline $\begin{array}{l}\text { IMS65, modified by plasma } \\
\text { in the allylamine medium }\end{array}$ & 861 & 844 & 963 & 157 \\
\hline
\end{tabular}

studies of carbon plastic using traditional and modified fillers were carried out on a PhenomPro microscope. For the studies, fragments of $10 \times 10 \times 1.5 \mathrm{~mm}$ were cut from each carbon-fiber shell of tube shape, destroyed during internal pressure tests.

Figure 2 shows the microstructure of the end surface of samples cut from carbon-fiber shells of tube shape based on $\mathrm{УKH/5000} \mathrm{carbon} \mathrm{fiber.} \mathrm{The} \mathrm{pres-}$ ence of microcracks between the layers for carbonreinforced plastics on all types of fibers has been established.

Such microcracks confirm the character of tightness loss and destruction of tube-shaped shells during internal pressure tests.

\section{Conclusions}

As a result of internal pressure tests, the characteristics of carbon-plastic tubular structures of different filling were obtained. Adhesion characteristics increasing at the interface of the filler-resin compound on models made of traditional (in the initial state) and modified fillers was confirmed. It was also found that the strength characteristics of carbon-plastic wound structures differ from similar ones obtained on plate samples. Therefore, to calculate the strength of carbon plastic structures, it is recommended to apply the characteristics of the composite obtained by winding at a given reinforcement angle. 


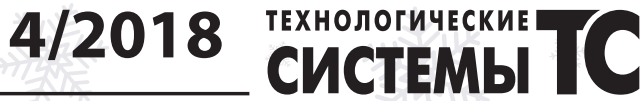

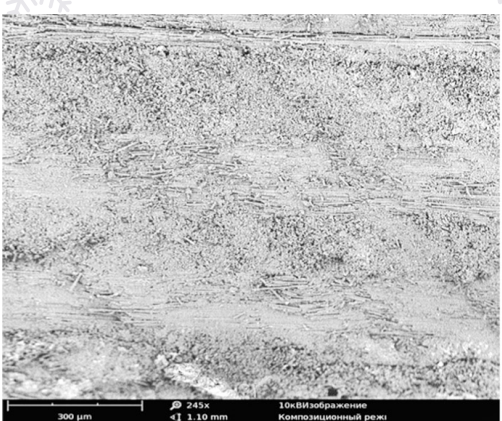

$\times 245$

УKH/5000 (traditional) carbon fiber

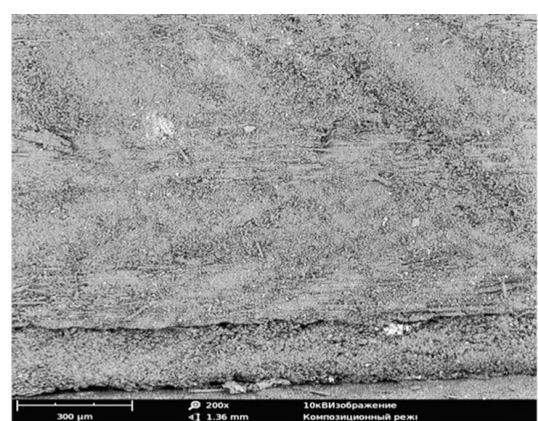

$\times 245$

УKH/5000 carbon fiber, modified by atmospheric plasma in the acrylic acid medium

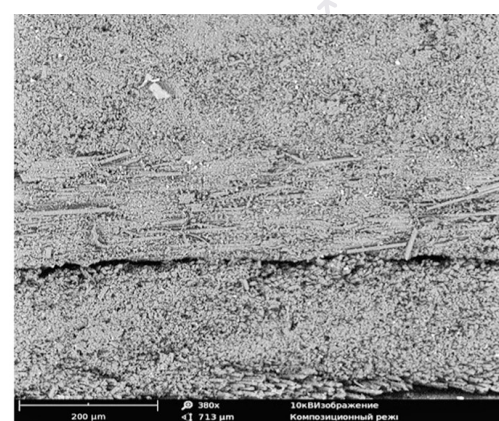

$\times 245$

УКH/5000 carbon fiber, modified by atmospheric plasma in the allylamine medium

Fig. 2. Microstructure of the end of UKN / 5000 carbon fiber tube models (traditional and treated with atmospheric plasma in different environments)

\section{References}

[1] Manko, T. A. Research of mechanical properties of carbon plastics with modified filler [Text] / T. A. Manko, I. A. Gysarova, O. P. Romenskaya, A. A. Samusenko // Technological systems. - \#1 (82). - 2018. -
P. 21-26. - ISSN 2074-0603. dx.doi.org/10.29010/ 082.4

[2] Bulanov, I.M. Technology of rocket and aerospace structures made of composite materials [Text] / I.M. Bulanov, B.B. Sparrow. - M: Publishing House of Moscow State Technical University. N.E. Bauman, 1998. - p.516

\section{УДК 620.171 .2}

Манъко Т. А. ${ }^{1}$, Гусарова И. А. ${ }^{2}$, Роменская О. П. ${ }^{2}$, Самусенко А. А. ${ }^{2}$, Деревянко И. И. ${ }^{2}$

${ }^{1}$ Днепропетровский национальный университет имени Олеся Гончара. Украина, г. Днепр

${ }^{2}$ Государственное предприятие «Конструкторское бюро «Южное»» им. М. К. Янгеля. Украина, г. Днепр

\section{ОЦЕНКА ПРОЧНОСТНЫХ СВОЙСТВ УГЛЕПЛАСТИКОВЫХ ТРУБЧАТЫХ КОНСТРУКЦИЙ ПРИ ВОЗДЕЙСТВИИ ВНУТРНЕЕГО ОДНООСНОГО ДАВЛЕНИЯ}

Углепластики иироко применяются в конструкциях ракет космического назначения. Это корпуса ракетных двигателей, элементы сопловых блоков, головные части и т.п. Характеристики применяемых материалов определяют на плоских образцах и моделях, имитирующих технологию изготовления конструкций.

В работе рассмотрено углепластики в составе трубчатых конструкций изготовленных из традиционных, а также модифицированных под воздействием плазменной обработки наполнителей. Проведено сравнительный анализ характеристик углепластика, полученных при механических испытаниях плоских образцов и испытаниях моделей внутренним давлением. [dx.doi.org/10.29010/085.9]

Ключевые слова: углепластик; плазма; трубчатая конструкция; испьтания.

Литература

[1] Манько, Т. А. Исследование механических свойств углепластиков с модифицированным наполнителем [Текст] / Т. А. Манько, И. А. Гусарова, О. П. Роменская, А. А. Самусенко // Технологические системы. - №1 (82). - 2018. C. 21-26. - ISSN 2074-0603. dx.doi.org/10.29010/082.4

[2] Буланов, И. М. Технология ракетных и аэрокосмических конст-рукций из композиционных материалов [Текст] / И.М. Буланов, В.В. Воробей. - М: Изд-во МГТУ им. Н.Э. Баумана, 1998. -c.516 